\title{
Where Did That Pollution Come From? A Review of Chemical and Microbial Markers of Organic Pollution
}

John J Harwood

${ }^{1}$ Department of Chemistry, Tennessee Technological University, Cookeville, TN, USA

*Corresponding author: John J Harwood, Department of Chemistry, Tennessee Technological University, Cookeville, TN, USA, Tel: +931 372-3473; E-mail: jharwood@tntech.edu

Received date: August 03, 2014; Accepted date: August 28, 2014; Published date: September 5, 2014

Copyright: (c) 2014 Harwood JJ, et al. This is an open-access article distributed under the terms of the Creative Commons Attribution License, which permits unrestricted use, distribution, and reproduction in any medium, provided the original author and source are credited.

\begin{abstract}
This review presents the current range of analytical markers which can be used to identify the sources of organic matter in environmental waters. Both chemical and microbial markers are presented. Applications which have been developed include identification of pollution input from human domestic sources, agriculture, landfills, and urban runoff. DNA and RNA characteristic of individual animal species, fecal sterols and bile acids, artificial sweeteners, commercial chemicals, and isotope ratios of carbon and hydrogen have been found useful as pollution markers. The review is intended to both introduce the reader to this vital area of research, and to present an overview which can be useful to practitioners in the field.
\end{abstract}

Keywords: Organic pollution; Molecular markers; Microbial markers; Microbial source tracking; MST; fecal sterols; Sucralose; Acesulfame-K; Bacteriodes

\section{Introduction}

While much research in recent years has focused on determining the extent of pollution by pharmaceuticals and personal care products in environmental waters, the traditional challenges of gross organic pollution (dissolved organic carbon, DOC) and contamination by pathogens in sewage remain. Reduction of these pollutants requires identifying the sources. One means of this is through the use of "markers". Both chemical and microbial markers are used.

\section{Impacts of DOC}

The impacts of DOC in waters are several. In consuming organic matter, bacteria deplete the dissolved oxygen content in water on which dersirable aquatic organisms, fish and macroinvertebrates, depend. The importance of this impact is shown by the ubiquitous use of the measure biochemical oxygen demand (BOD), the oldest and the most common method for assessing biodegradable organic contaminants in water and wastewater [1]. In unpolluted waters, DOC can range from $1 \mathrm{mg} / \mathrm{L}$ to greater than $20 \mathrm{mg} / \mathrm{L} \mathrm{[2-4].} \mathrm{Without}$ reaeration, just $3.1 \mathrm{mg} / \mathrm{L}$ DOC will deplete oxygen in water [5] Depleted oxygen can result in a buildup of toxic ammonia and hydrogen sulphide [1]. Degradation of DOC may release nutrient phosphorus to water, and lowers $\mathrm{pH}$ through a build-up of $\mathrm{CO}_{2}$. Lower $\mathrm{pH}$ and oxygen lowers redox potential, facilitating desorption of toxic metal ions from sediments. These physico-chemical impacts reduce biodiversity in aquatic systems.

DOC is also the most important factor influencing drinking water treatment costs [4]. Degradation of DOC in source water through chlorination produces hazardous disinfection byproducts, trihalomethanes and haloacetic acids [6,7].
Depending on the source, DOC in water may include priority pollutants [8]. The Nationwide Urban Runoff Program conducted by the US Environmental Protection Agency in the early 1980's found 14 toxic organic compounds, predominantly polycyclic aromatic hydrocarbons (PAH), in more than $10 \%$ of samples [9]. These results continue to be observed in United States stormwater runoff [10].

Pollution from pulp and paper mills has a large variety of toxic effects on aquatic communities [11]. A significant number of these pollutants are classified as carcinogenic, mutagenic or endocrine disrupting. This pollution can both cause fish kills and affect the reproductive physiology of fish. Coking processes, oil production, pulp mills, textile production, and tanneries all significantly elevate BOD in receiving waters $[3,11-14]$. These sources also release many toxic compounds including PAH, organic solvents, phenolic compounds, and dioxin and other chlorination products. Landfills contribute BOD and toxic organic compounds as well, including benzene and other volatile organic compounds $[8,15]$.

Even large rivers can be heavily degraded by uncontrolled organic pollution, as is documented by Kumar and Wata in the case of the Ganga River [3]. Before efforts to reduce organic pollution from industry and domestic sources in Kanpur, India, in 1987 this river had nearly been reduced to "an ecological desert". A "much reduced" fish production in Mumbai Harbor and the Uhas River estuary has been attributed to organic pollution [14]. In rural areas, DOC from agricultural fields strongly impacts receiving water quality [16].

The US EPA National Water Quality Inventory in 2004 found that of $16 \%$ of total river and stream miles reported on in the United States, $44 \%$ were impaired or not clean enough to support their designated uses [17]. Organic enrichment/oxygen depletion was a source of impairment in $17 \%$ of these impaired stream miles. The top sources of impairment included agricultural activities (38\%) and municipal discharges/sewage (15\%). This report also found $30 \%$ of the $29 \%$ of total area of U.S. bays and estuaries assessed were reported to be impaired. Organic enrichment/oxygen depletion was again a major cause of pollution, impairing $29 \%$ of impaired stream miles. 
Agricultural activities (11\%) and municipal discharges/sewage (33\%) again accounted for most of this source of impairment.

\section{Applications of Source Markers}

Zgheib et al. present a very innovative example of using chemical source markers to study organic matter in combined wet weather flows containing domestic wastewater and runoff storm water in Paris [18]. This water contains organic particles from three main sources: runoff water, domestic wastewater and erosion of an organic in-sewer deposit. Vegetable and animal sterols (stigmastanol, $\beta$-sitosterol and cholestanol) can be found in runoff water, whereas different fecal sterols are expected to be found in in-sewer stocks and wastewater. Eight sterols were selected to distinguish between the sources of organic matter: cholesterol, cholestanol, fecal sterols (coprostanol epicoprostanol, coprostanone), and phytosterols ( $\beta$-sitosterol, stigmasterol, stigmastanol).

The sterol profile of wastewater was found to be slightly different from that of in-sewer deposits [18]. It is characterized by similar abundances of cholesterol (30-49\%) and coprostanol (34-52\%), and a low percentage of other sterols. Biofilm is distinguished from other sewer deposits by the highest abundance of $\beta$-sitosterol (13-20\%), coprostanol between 30 and 35\%, and cholesterol 27-38\%. Roof and street runoff were found to contain the same individual sterols, especially cholesterol, $\beta$-sitosterol and stigmasterol, with a total absence of fecal sterols.

As in other studies utilizing these markers, principal component analysis (PCA) was applied to help interpret the rather complex results of the sterol profiles [18]. This analysis found both sterol profiles to be similar between the combined wet weather flows, wastewater and the organic layer deposits, while gross bed sediment and runoff clusters are far apart.

As discussed below, researchers have explored using molecular markers to source pollution from treated and untreated domestic wastewater, agricultural runoff, and urban runoff and landfill leachate. Microbial markers are used to determine sewage impacts on recreational waters and shellfish production.

\section{Detecting contamination by sewage and treated wastewater}

Organic contamination from human and animal sources is often accompanied by microbial and viral contamination, constituting a public health concern. Both biological and chemical markers have been employed to detect this contamination with a series of analytical methods referred to as "Microbial Source Tracking" (MST) [19]. Traditionally, the presence of indicator bacteria in water, Escherichia coli (E. coli) or fecal coliform, and enterococci, has been tested to determine possible contamination by human sewage. However, these indicators require time-consuming bacterial culturing and are found to not be specific to human sewage [20]. Indeed, one river basin-wide study which compared different fecal indicators found a "tighter linkage between E. coli counts and ruminant source markers than between E. coli counts and human markers" [21]. More advanced techniques have been developed for water analysis, most commonly based on DNA or RNA analysis utilizing polymerase chain reaction (PCR) technology, and also on antiobiotic resistance profiling.

Antibiotic resistance analysis (ARA) consists of culturing the bacteria in a water sample on a series of media containing a variety of antibiotics. A phenotype library must be assembled prior to application of the test. This library documents the resistance of bacteria which may present in waste to the different antibiotitics. These bacteria are characteristic of different animal species which may release waste to the water. The antiobiotic resistance is encoded in plasmids, which may be lost or uptaken by bacteria, which puts in question the stability of the libraries [19]. ARA has been observed to produce a high level of false-positive results [22].

The most common PCR target for identification of bacterial sources in water has been $16 \mathrm{~S}$ ribosomal DNA and RNA [23]. The bacteria probed are the genus Bacteroides, which are obligate anaerobes and are among the most numerous bacteria in human and animal intestines [19]. The PCR technique is relatively rapid as it does not require cell culturing. This technique can be used to detect human fecal sources in fresh and marine waters, and it can identify other fecal sources such as ruminants, dogs, pigs, and horses [23]. PCR is labor intensive, however, and a finger-print library is again required [19]. Liu et al. have suggested that the observed lack of specificity, leading to frequent false positives, is due to the inability of PCR to discriminate between sequences having "single internal mismatches" [24]. This group designed primers with more pronounced differences in sequence between bacteria species. A study of potential regional variability in applying PCR assays in MST tested 280 samples from 16 countries across six continents [25]. Ruminant associated marker concentrations correlated strongly with total intestinal Bacteroidetes populations and with each other, indicating that the detected ruminant-associated populations seem to be part of the intestinal core microbiome of ruminants worldwide. However, human-targeted assays were of relatively low specificity, indicating strong need for improved human-targeted assays.

Chemical markers of human sewage have also been studied as indicators of the potential presence of human pathogens. Murtaugh and Bunch first suggested coprostanol $(5 \beta(\mathrm{H})$-cholestan-3 $\beta$-ol), a product of the bacterial degradation of cholesterol in the human gut, be used as an indicator of human pollution [26]. Many studies have since been conducted associating coprostanol in water with sewage contamination. Other fecal sterols as well as bile acids have been enlisted in attempting to source human sewage input into waters [27].

Isobe et al. used sterol markers to perform regional monitoring of sewage impact in Malaysia and Vietnam [28]. This study demonstrated two great advantages of sterols as molecular markers, stability and transportability. The compounds are more stable in storage than are bacteria. Also, sterols concentrate in particulate matter, and so are collected from water samples on filters which can be easily transported. In the study gas chromatography-mass spectrometry was used to analyze for ten sterols at 59 sampling stations. The results showed $\mathrm{C}_{27}$ sterols to be abundant in urban areas, with coprostanol and cholesterol predominating, and significanly $\mathrm{C}_{29}$ sterols, indicative of ruminants, were depleted. These sterol profiles were typical of those previously observed in areas with heavy sewage impact. In rural areas, $C_{29}$ sterols, including $\beta$-sitosterol and stigmastanol, were dominant while only trace amounts of coprostanol were found; this indicates contamination by non-human sources. A strong linear relationship was observed between concentrations of coprostanol and E. coli in both Malaysia and Vietnam.

Laundry detergent components find their way into environmental waters and serve as good markers of wastewater. Linear alkylbenzenes (LABs) were identified in the 1990's to be useful in this application. LABs are manufactured for the production of the linear alkylbenzenesulfonate surfactants used in commercial detergent 
formulations, and are present as minor components in detergents. LABs concentrate in suspended particulate matter and sediment, where they are found generally in sub- $\mu \mathrm{g} / \mathrm{L}$ or in $\mu \mathrm{g} / \mathrm{g}$ concentrations (dry weight), respectively [29]. In secondary water treatment, microbial alteration results in depletion of the "external isomers," where the benzene ring is attached near the end of the alkyl chain, with enrichment of "internal isomers." The ratio of these isomers can be used to indicate whether contamination is from secondary treatment (high "I/E") or untreated or primary treatment discharge (low "I/E") $[30,31]$.

Takada et al. studied LABs and other markers in the Tokyo Bay and in a deep ocean dumpsite off the eastern seaboard of the United States [32]. The markers showed where sewage residue concentrates in the bay. Also, sedimentation rates can be estimated using the correlation between alkylbenzene production and sediment alkylbenzene concentration with depth [33-35]. Isobe et al. performed a large-scale monitoring project using LABs to show the wide-spread contamination by untreated sewage of canals and rivers in Southeast Asia [31].

Laundry fluorescent whitening agents (FWA) are also molecular markers for municipal and domestic wastewaters. The two most used detergent fluorescent whiteners are DSBP, a distyrylbiphenyl FWA, and DAS 1, a diaminostilbene [36]. Whiteners are subject to "photofading," isomerization to non-fluorescent geometric isomers, and photolysis. Hyashi et al. used these makers to track wastewater effluents from sewage treatment through rivers and estuaries and into Tokyo Bay [37]. Apparently due to a difference in photodegradation rate, the ratio DSBP/DAS1 was found to decrease as the water travelled. This ratio can be used to indicate fresh verses aged sediments [38], and to make inferences concerning sedimentation processes [39].

Artificial weeteners used in beverages and other products are now found widespread in environmental waters and can serve as markers of wastewater. Sucralose and acesulfame- $\mathrm{K}$ are both very stable and water soluble, resisting metabolism, decomposition and loss through adsorption in wastewater treatment and in the environment. In a large sampling of Swiss wastewater treatment plants, rivers, lakes and groundwater, acesulfame- $\mathrm{K}$ was consistently detected in untreated and treated wastewater $(12-46 \mu \mathrm{g} / \mathrm{L})$, in most surface waters, in $65 \%$ of investigated groundwater samples, and even in several tap water samples (up to $2.6 \mu \mathrm{g} / \mathrm{L}$ ) [40]. Sucralose has been measured in surface waters of 27 European countries [41] and in fresh and marine waters of the United States $[42,43]$.

\section{Distinguishing agricultural pollution}

Analysis of viruses has been explored in sourcing animal waste. Adenoviruses have been suggested as indicating contamination of human origin [44]. Formiga-Cruz et al. used PCR to analyze for adenoviruses, enteroviruses and hepatitis $\mathrm{A}$ virus in shellfish and sewage samples. The method was found to be as or more sensitive than testing for fecal coliforms or bacteriophages. As in previous studies, all samples testing positive for enteroviruses or hepatitis A virus were also positive for human adenoviruses, hence the latter viruses may simplify future pollution assays.

Gourmelon et al. have combined biological and chemical markers to produce a "MST Toolbox" to trace the origin of the fecal pollution $[45,46]$. The group recommends for distinguishing human pollution the markers caffeine, TCEP and benzophenone and the steroid ratios sitostanol/coprostanol and coprostanol/(coprostanol +24 ethylcoprostanol). PCR analysis of bacterial markers HF183 and Bifidobacterium adolescentis and genotype II of FRNAPH were determined to be indicators of human pollution. For porcine and ruminant pollution, the use of the same steroid ratios and PCR bacterial markers Pig-2-Bac and Lactobacillus amylovorus (porcine) and Rum-2-Bac (ruminants) was found adequate. The markers function best when the level of coliform in water is above $500 \mathrm{cfu}$.

Significant progress has been achieved in distinguishing pollution from agricultural production of different animals through analysis of profiles of fecal sterols, which vary between animal species. Recently, bile acids have been combined with fecal sterols to more definitively identify waste from individual animal species.

Leeming et al. published a groundbreaking analysis of feces from humans and 14 species of animals in which 17 sterols were identified [47]. Principal component analysis (PCA) was applied to analyze sterols contents. Cows and sheep, humans, and hens, which group with dogs and cats, are clearly distinguished from each other by this analysis. Distinguishing sterol markers include coprostanol ( $60 \%$ of the total sterols in human feces), C29 sterols and $5 \beta$-stanols, which dominate the sterol profiles of herbivores, and $5 \beta$ - and $5 \alpha$ - stanols, which were found in very low occurrence in birds and dogs feces. The sterol content of bird feces was found to be extremely variable and largely dependent on the diet of the animals. Only cats and pigs were found to have fecal sterol profiles similar to that of humans. While analysis of feces from individual animals produces clear distinctions between sources, mixed source samples can produce "confounding results" in source identification [48]

Jardé et al. used the sterol ratios $\left(\mathrm{C}_{29}+\mathrm{C}_{28}\right) / \mathrm{C}_{27}$ and $5 \beta / \mathrm{C}_{27}$ to distinguish animal sources in five rivers in Brittany, the principal animal production and dairy region of France [49]. Cross-plots of the sterol ratios contained in river particulate against type of manure spread in the watersheds clearly indicate a systematic relationship between sterol ratios and the type of animal breeding or animal manure spreading on their catchments. This work was continued to find that PCA analysis of six stanols can clearly distinguish bovine, porcine, and human feces [50]. The analysis successfully identified these individual sources of contamination in three river basins in France, with the results being verified through microbial analysis.

Building on previous work with molecular markers in archeology studies, Bull et al. present a multiple biomarker analysis flowchart for identifying individual animal sources using $5 \beta$-stanols and bile acids [27]. Like the sterols, bile acids concentrate in particulates and sediment. Clearly, adding a second class of compounds can increase the power of discrimination in delineating sources of fecal pollution. For instance, the presences of hyocholic acids in porcine fecal material enable it to be distinguished from human and canine contamination.

To assess the contribution of domesticated animal sources of fecal pollution, Tyagi et al. derived a multiple regression model with selected fecal sterols and bile acids [51]. Five compounds were found to determine to identify pollution sources efficiently: epicoprostanol, cholesterol, cholestanol, chenodeoxycholic acid, and hyodeoxycholic acid. Almost $100 \%$ accuracy was obtained in identifying sources when measuring compounds from runoff from test plots. 


\section{Organic Pollution from Non-Animal Sources}

\section{Landfill leachate}

Municipal landfill leachate can add signicant organic matter to receiving waters [15]. Trace but potentially ecologically harmful components of landfill leachate include phthalates, alkylphenols and polynuclear aromatic hydrocarbons, persistent organic pollutants, including polychlorinated biphenyls and chlorinated pesticides, and volatile organic compounds, including chlorinated solvents [52-55]. Even as some hazardous materials used in commerce are phased out, new ones, such as brominated and fluorinated compounds are introduced [54]. These compounds may be so stable as to outlast integrity of engineered landfills, so may leach and impact environmental waters well into the future. While many of the components have low water solubility, the compounds are solubilized through association with soluble organic colloids in the leachates [52].

Fourie has noted that a unique feature of landfill leachate is that both inorganic and organic contaminants have high concentrations [56]. He suggests two ratios may serve as a "first pass testing protocol": A - COD $\mathrm{x}$ sulphate, and B - chloride $\mathrm{x}$ iron $\mathrm{x}$ ammonia; COD is chemical oxygen demand. In landfill leachate, both these ratios will be typically greater than 105 and 104, respectively.

In a relatively early detailed study of organic constituents leaching from a Barcelona, Spain sanitary landfill, seventeen carboxylic acids and a host of phenolics, alcohols and phthalates were identified [57]. These researchers suggested the gas chromatographic profile of shortchain organic acids, derivatized with pentafluorobenzyl bromide to allow selective detection with the electron capture detector, could be used to identify leachate pollution in groundwater. The series of C4 C7 carboxylic acids was clearly recognizable in sampled groundwater and exhibited patterns similar to those of leachate. The predominance of the even carbon numbered acids, with a greater abundance of hexanoic acid, "may reflect" $\beta$-oxidation sequence characteristic of long-chain fatty acid oxidation.

Schwarzbauer et al. used gas chromatography-mass spectrometry to analyze seepage from a municipal landfill in Germany [58]. Given the high degree of stability and similarly high concentrations of some compounds measured in the landfill seepage and leakage waters, these authors suggested compounds which might serve as markers of water pollution from municipal landfills: the pharmaceutical propyphenazone, the plasticizer N-butyl benzene sulfonamide, and the insecticide $\mathrm{N}, \mathrm{N}$-diethyl toluamide (DEET). Clofibric acid, a plasticizer, and the herbicide mecoprop were also commonly detected. A continuation of this work used these five compounds to study lateral and vertical distribution of contamination as well as the long-term emission from the landfill [59].

Alkyl organotin compounds might serve as unique makers of landfill leachate. These compounds are used as PVC stabilizers, wood preservatives, pesticides, fungicides, and polyurethane and silicone catalysts $[60,61]$. While not found at levels considered hazardous to the environment, the compounds are found in landfill leachates at levels as high as $229 \mathrm{ng} / \mathrm{L}$. Analysis can be achieved by gas chromatography-inductively coupled plasma mass spectrometry.

Bergström et al. have developed a comprehensive scheme for evaluation of landfill leachate treatment processes which may suggest useful markers [62]. The "LAQUA protocol" includes analysis of organic compounds, metals, inorganic ions, water-quality parameters, and toxicity. Polar organic compounds are represented by phenol and several phenolic compounds including 3-methyl-4-chlorophenol. A polychlorinated biphenyl reference standard was chosen to monitor removal of these compounds during treatment.

To characterize the biogeochemical evolution of DOC in landfill leachates, and to interpret the origin of DOC in groundwater, Mohammadzadeh et al. developed a technique to distinguish carbon isotope ratios in small organic acids [63]. The analytical technique, which interfaces a high performance liquid chromatograph to an isotope ratio mass spectrometer, was used to analyze leachate from a municipal landfill near Ottawa, Canada. The group found a difference in $\delta^{13} \mathrm{C}$ values for leachate acetate $(-10.7 \%$ o to $-16.9 \%$ VPDB) and the "precursor" DOC within the landfill $(-24.7 \%)$. The enrichment of $\delta^{13} \mathrm{C}$ in the acetate suggests secondary biogeochemical reaction, likely methanogenesis, removes the lighter ${ }^{12} \mathrm{C}$ from the leachate.

This approach was expanded to include potential changes in nitrogen isotope composition in leachates [64]. Leachate from a municipal solid waste landfill in New Zealand were analyzed for changes in ${ }^{13} \mathrm{C}$ composition in dissolved inorganic carbon (DIC), ${ }^{15} \mathrm{~N}$ in nitrate and ammonia nitrogen, and isotopic changes in particulate organic matter. Landfill leachate was found to have a distinct isotopic signature characterized by highly enriched 13C-DIC and highly enriched ${ }^{15} \mathrm{~N}-\mathrm{NH}_{4}{ }^{+}$. Downstream sites had ${ }^{15} \mathrm{~N}$ values approaching those of the leachate, elevated above both upstream and reference stream site waters. The contrasting decrease in ${ }^{15} \mathrm{~N}_{-} \mathrm{NO}_{3}{ }^{-}$values may be explained by isotope selection during nitrification. ${ }^{13} \mathrm{C}$ - DIC was enriched in landfill leachate and downstream sites; this enrichment is explained by isotope selection during bacterial methanogenises.

Tritium levels may also be indicative of landfill leachate [56]. Luminescent paint used in watches and other devices is apparently the source. In leachates from landfills throughout the world tritium has been measured at levels from 10 to 20,000 times background levels. A significant advantage of this tracer is that it is conservative, unaffected by processes such as ion exchange and adsorption that can affect concentrations of other contaminants moving through subsurface geology.

\section{Road runoff}

Organic pollution from roads is a major source of PAH among other toxic pollutants [65]. However, using PAH as road runoff markers is complicated by the presence of the compounds in waters from other sources including power, residential heating, industrial activities, by the changing composition of fuels, and by evolving emission controls used with these sources [66]. Building on previous work of Spies et al. [67], researchers have analyzed tire rubber components 2-(4-morpholinyl)benzothiazole (24MoBT) and $\mathrm{N}$ cyclohexyl-2-benzothiazolamine (NCBA), benzothiazolamines present in different vulcanization accelerators, as markers of road runoff in urban sediments in Japan [68]. Sediment cores were dated using Cs-137 and tetrapropylene-based alkylbenzenes. "Changeovers" in the concentrations of the markers in sediments coincide well with changes in the production history of vulcanization accelerators. The dated downcore profile of $24 \mathrm{MoBT}$ and NCBA show positive correlation with the traffic data in the Tokyo Metropolitan Area.

Nitro-PAHs and triphenylene have been compared with sulfurPAHs as markers of urban stormwater road runoff [69]. Based on abundance, source specificity, and persistence, dibenzothiophene and triphenylene were judged the most promising among the candidate 
markers. This study found $24 \mathrm{MoBT}$ to photodegrade rapidly in the aqueous phase and to not concentrate in sediment, limiting the potential usefulness of this marker. The ratio of 1-nitropyrene to total $\mathrm{PAH}$ has been found to be a useful indicator of road runoff from diesel fueled as compared with gasoline fueled vehicles [70]. Cluster analysis of tri-terpenes can distinguish atmospheric dust from road dust [71].

\section{Conclusion}

This review has focused on chemical and microbial markers used in determining sources of pollution. The underlying story is how the development of increasingly powerful analytical tools has allowed progress in this area. Originally pollution was monitored visually, then through laborious bacterial culturing techniques. In the 1990's, high resolution gas chromatography-mass spectrometry could be applied to analyze for steroid markers and xenobiotic organic compounds. A decade later, high performance liquid chromatography-mass spectrometry has added the capability to readily analyze for polar compounds, including artificial sweeteners. PCR analysis of nucleic acids is being applied to identify bacteria in water corresponding to pollution from specific animal hosts. This technical innovation has greatly expanded the potential applications of pollution source identification through analysis of chemical and microbial markers. From the large array of potential markers, the work of many researchers has refined the science to the point that a relatively short list of the most useful markers may be selected for common use. As more studies are performed, quantitative relationships between marker concentrations and associated pollution may be developed. Rapid, definitive identification and delineation of pollution sources through analysis of source markers seems very possible in coming years.

\section{References:}

1. PK Goel (2009) Water Pollution: Causes, Effects and Control. (Revised 2ndedn), New Age International Pvt Ltd New Delhi.

2. Carvalho P, Thomaz S M, Bini LM (2003) Effects of water level, abiotic and biotic factors on bacterioplankton abundance in lagoons of a tropical floodplain (Paraná River, Brazil). Hydrobiologia 510: 67-74.

3. Kumar, Amit, Wata (2003) Impact of Manmade Environmental Degradations on the Chemical Composition and Organic Production in River Ganga at Kanpur. Research Journal of Chemistry and Environment 7: 63-66.

4. Cox, JW, Ashley R (2000) Water quality of gully drainage from texturecontrast soils in the Adelaide Hills in low rainfall years. Australian Journal of Soil Research 38: 959-972.

5. Langmuir, Donald (1997) Aqueous Environmental Geochemistry. Prentice Hall, Upper Saddle River, New Jersey.

6. Wassink JK, Andrews RC, Peiris RH, Legge RL (2011) Evaluation of fluorescence excitation-emission and LC-OCD as methods of detecting removal of NOM and DBP precursors by enhanced coagulation. Water Science \& Technology: Water Supply 115: 621-630.

7. Kraus, Tamara EC, Anderson, Chauncey A Morgenstern, Karl, Downing, Bryan D, Pellerin, Brian A, Bergamaschi, Brian A (2010) Determining Sources of Dissolved Organic Carbon and Disinfection Byproduct Precursors to the McKenzie River, Oregon. Journal of Environmental Quality 39: 2100-2112.

8. Hallbourg, Robin R, Delfino, Joseph J, Miller WL (1992) Organic priority pollutants in groundwater and surface water at three landfills in north central Florida. Water, Air, and Soil Pollution 65: 307-22.

9. Boving, Thomas B, Stolt, Mark H, Augenstern, Janelle, Brosnan, Brian (2008) Potential for localized groundwater contamination in a porous pavement parking lot setting in Rhode Island. Environmental Geology 55: 571-582.

10. Bathi JR, Pitt R, Clark SE (2009) Associations of PAHs with size fractionated sediment particles. 2009 World Environmental and Water Resources Congress Proceedings, Kansas City, MO. 18-22.

11. Karrasch B, Parra O, Cid H, Mehrens M, Pacheco P (2006) Effects of pulp and paper mill effluents on the microplankton and microbial selfpurification capabilities of the Biobío River, Chile. Science of the Total Environment 359: 194-208.

12. Mrkva, Miroslav (1975) Automatic UV-control system for relative evaluation of organic water pollution. Water Research 9: 587-589.

13. Lundegard, Paul D, Jeffrey RK (2001) Polar Organics in Crude Oil and Their Potential Impacts on Water Quality. Petroleum Hydrocarbons and Organic Chemicals in Ground Water: Prevention, Detection, and Remediation, Conference and Exposition, Houston, TX.

14. Chavan RP, Lokhande RS, Rajput SI (2005) Monitoring of organic pollutants in Thane Creek water. Nature Environment and Pollution Technology 4: 633-636.

15. Castrillón L1, Fernández-Nava Y, Ulmanu M, Anger I, Marañón E (2010) Physico-chemical and biological treatment of MSW landfill leachate. Waste Manag 30: 228-235.

16. Udeigwe, Theophilus K, Wang, Jim J (2010) Biochemical Oxygen Demand Relationships in Typical Agricultural Effluents. Water, Air, and Soil Pollution 213: 237-249.

17. USEPA (2009) National Water Quality Inventory: Report to Congress 2004 Reporting Cycle EPA 841-R-08-001. United States Environmental Protection Agency Office of Water Washington, DC.

18. Zgheib S1, Gromaire MC, Lorgeoux C, Saad M, Chebbo G (2008) Sterols: a tracer of organic matter in combined sewers. Water Sci Technol 57: 1705-1712.

19. Seurinck, Sylvie, Verstraete, Willy, Siciliano, Steven D (2005) Microbial source tracking for identification of fecal pollution. Reviews in Environmental Science and Bio/Technology. 4: 19-37.

20. Shanks, Orin C, Nietch, Christopher, Simonich, Michael, Younger, Melissa, Reynolds, Don Field, Katharine G (2006) Basin-Wide Analysis of the Dynamics of Fecal Contamination and Fecal Source Identification in Tillamook Bay, Oregon. Applied and Environmental Microbiology 72: 5537-5546.

21. Glassmeyer, Susan T, Urlong, Edward TF, Kolpin, Dana W, Cahill, Jeffery D, Zaugg, Steven D et al. (2005) Transport of Chemical and Microbial Compounds from Known Wastewater Discharges: Potential for Use as Indicators of Human Fecal Contamination. Environmental Science \& Technolology. 39: 5157-5169.

22. Harwood VJ, Wiggins BA, Hagedorn C, Ellender RD, Gooch J (2003) Phenotypic library-based microbial source tracking methods: Efficacy in the California collaborative study. Journal of Water and Health 1: 153166.

23. Bernhard AE1, Goyard T, Simonich MT, Field KG (2003) Application of a rapid method for identifying fecal pollution sources in a multi-use estuary. Water Res 37: 909-913.

24. Liu R1, Chan CF, Lun CH, Lau SC (2012) Improving the performance of an end-point PCR assay commonly used for the detection of Bacteroidales pertaining to cow feces. Appl Microbiol Biotechnol 93: 1703-1713.

25. Reischer GH1, Ebdon JE, Bauer JM, Schuster N, Ahmed W, et al. (2013) Performance characteristics of qPCR assays targeting human- and ruminant-associated bacteroidetes for microbial source tracking across sixteen countries on six continents. Environ Sci Technol 47: 8548-8556.

26. Georg HR, James EE, Johanna MB, Nathalie S, Warish A, Johan Å, Anicet RB, Günter B, Denis B, Tricia C, Christobel F, Goraw G, GwangPyo K, Ana Maria de RH, Douglas M, Ramiro P, Bandana P, Veronica R, Margit AS, Regina S, Huw T, Erika MT , Virgil V, Stefan W, Robert LM, Andreas HF (2013) Performance Characteristics of qPCR Assays Targeting Human- and Ruminant-Associated Bacteroidetes for Microbial Source Tracking across Sixteen Countries on Six Continents. Environmental Science \& Technology. 47: 8548-8556. 
27. Murtaugh JJ, Bunch RL (1967) Sterols as a measure of fecal pollution. J Water Pollut Control Fed 39: 404-409.

28. Bull ID1, Lockheart MJ, Elhmmali MM, Roberts DJ, Evershed RP (2002) The origin of faeces by means of biomarker detection. Environ Int 27: 647-654.

29. Isobe, Kei O, Tarao, Mitsunori, Zakaria, Mohamad P, Chiem, Nguyen H, Minh, Le Y (2002) Quantitative Application of Fecal Sterols Using Gas Chromatography-Mass Spectrometry to Investigate Fecal Pollution in Tropical Waters: Western Malaysia and Mekong Delta, Vietnam Environmental Science \& Technolology 36: 4497-4507.

30. Takada, Hideshige, Eganhouse, Robert P (1998) Molecular Markers of Anthropogenic Waste, in: Robert A Meyers, The Encyclopedia of Environmental Analysis and Remediation, Vol 5 John Wiley \& Sons, Inc, Hoboken, New Jersey.

31. Tsutsumi S1, Yamaguchi Y, Nishida I, Akiyama K, Zakaria MP, et al. (2002) Alkylbenzenes in mussels from South and South East Asian coasts as a molecular tool to assess sewage impact. Mar Pollut Bull 45: 325-331.

32. Isobe KO1, Zakaria MP, Chiem NH, Minh le Y, Prudente M, et al. (2004) Distribution of linear alkylbenzenes (LABs) in riverine and coastal environments in South and Southeast Asia. Water Res 38: 2448-2458.

33. Takada, Hideshige, Satoh, Futoshi, Bothner, Michael H, Tripp, Bruce W, Johnson, Carl G (1997) Anthropogenic Molecular Markers: Tools to Identify the Sources and Transport Pathways of Pollutants. In: Molecular Markers in Environmental Geochemistry ACS Symposium Series Vol 671, American Chemical Society, Washington, DC.

34. Eganhouse RP, Pontolillo J, Leiker TJ (2000) Diagenetic fate of organic contaminants on the Palos Verdes Shelf, California. Marine Chemistry 70: 289-315.

35. Eganhouse RP, Pontolillo J (2000) Depositional history of organic contaminants on the Palos Verdes Shelf, California. Marine Chemistry 70: 317-338.

36. Boonyatumanond R, Wattayakorn G, Amano A, Inouchi $\mathrm{Y}$, Takada $\mathrm{H}$ (2007) Reconstruction of pollution history of organic contaminants in the upper Gulf of Thailand by using sediment cores: First report from Tropical Asia Core (TACO) project. Marine Pollution Bullutin 54: 554-565.

37. Poiger, Thomas, Karim Franz Günter, and Giger, Walter (1999) Fate of Fluorescent Whitening Agents in the River Glatt. Environmental Science \& Technology 33: 533-539.

38. Hayashi Y, Managaki S, Takada H (2002) Fluorescent Whitening Agents (FWAs) in Tokyo Bay and adjacent rivers: their application as anthropogenic molecular markers in coastal environments. Environmental Science \& Technology. 36: 3556-3563.

39. Managaki S, Takada H (2005) Fluorescent Whitening Agents in Tokyo Bay sediments: Molecular evidence of lateral transport of land-derived particulate matter. Marine Chemistry 95: 113-127.

40. Buerge Ignaz J, Buser, Hans-Rudolf, Kahle, Maren, Muller, Markus D, Poiger, Thomas (2009) Ubiquitous Occurrence of the Artificial Sweetener Acesulfame in the Aquatic Environment: An Ideal Chemical Marker of Domestic Wastewater in Groundwater. Environmental Science \& Technology. 43: 4381-4385.

41. Loos R, Gawlik B, Boettcher K, Locoro G, Contini S, Bidoglio G (2009) Sucralose Screening in European Surface Waters Using a Solid-phase Extraction-liquid Chromatography-triple Quadrupole Mass Spectrometry Method. Journal of Chromatography. 1216: 1126-131.

42. Mead, Ralph N, Morgan, Jeremy B, Avery Jr, Brooks, G, Kieber, Robert J, Kirk, Aleksandra M (2009) Occurrence of the artificial sweetener sucralose in coastal and marine waters of the United States. Marine Chemistry. 116: 13-17.

43. Mawhinney, Douglas B, Young, Robert B, Vanderford, Brett J, Borch, Thomas, Snyder, Shane A (2011) Artificial Sweetener Sucralose in U.S Drinking Water Systems. Environmental Science \& Technology 45: 8716-8722.

44. Formiga-Cruz, Meritxell, Hundesa, Ayalkibet, Clemente-Casares, Pilar, Albinana-Gimenez, Nestor, Allard, Annika (2005) Nested multiplex PCR assay for detection of human enteric viruses in shellfish and sewage. Journal of Virological Methods 125: 111-118.

45. Mieszkin S1, Furet JP, Corthier G, Gourmelon M (2009) Estimation of pig fecal contamination in a river catchment by real-time PCR using two pig-specific Bacteroidales 16S rRNA genetic markers. Appl Environ Microbiol 75: 3045-3054.

46. Gourmelon M1, Caprais MP, Mieszkin S, Marti R, Wéry N, et al. (2010) Development of microbial and chemical MST tools to identify the origin of the faecal pollution in bathing and shellfish harvesting waters in France. Water Res 44: 4812-4824.

47. Leeming R, Ball A, Ashbolt N, Nichols P (1996) Using Faecal Sterols from Humans And Animals to Distinguish Faecal Pollution in Receiving Waters. Water Research. 30: 2893-2900.

48. Shah, Vikaskumar G, Dunstan, R Hugh, Geary, Phillip M, Coombes, Peter, Roberts, Timothy K (2007) Evaluating potential applications of faecal sterols in distinguishing sources of faecal contamination from mixed faecal samples. Water Research 41: 3691-3700.

49. Jardé, Emilie, Gruau, Gérard, Mansuy-Huault, Laurence (2007) Detection of manure-derived organic compounds in rivers draining agricultural areas of intensive manure spreading. Applied Geochemistry 22: $1814-1824$

50. Derrien M1, Jardé E, Gruau G, Pourcher AM, Gourmelon M, et al. (2012) Origin of fecal contamination in waters from contrasted areas: stanols as Microbial Source Tracking markers. Water Res 46: 4009-4016.

51. Tyagi, Punam, Edwards, Dwayne R, Coyne, Mark S (2007) Use of selected chemical markers in combination with a multiple regression model to assess the contribution of domesticated animal sources of fecal pollution in the environment. Chemosphere. 69: 1617-1624.

52. Kalmykova, Yuliya, Björklund, Karin, Strömvall, Ann-Margret, Blom, Lena (2013) Partitioning of polycyclic aromatic hydrocarbons, alkylphenols, bisphenol A and phthalates in landfill leachates and storm water. Water Research 47: 1317-1328.

53. Castillo M, Barceló D (2001) Characterization of organic pollutants in textile wastewaters and landfill leachate by using toxicity-based fractionation methods followed by liquid and gas chromatography coupled to mass spectrometric detection. Analytica Chimica Acta 426 : 253-264.

54. Weber, Roland, Watson, Alan, Forter, Martin, Oliaei, Fardin (2011) Persistent organic pollutants and landfills - A review of past experiences and future challenges. Waste Management \& Research. 29: 107-121.

55. Sabel, Gretchen V, Clark, Thomas P (1984) Volatile organic compounds as indicators of municipal solid waste leachate contamination. Waste Management \& Research. 2: 119-130.

56. Fourie ABA, De Mello, Luiz Guilherme, Almeida, Marcio (2002) Strategy to determine if a landfill is the source of detected water pollution. In: Environmental Geotechnics, Proceedings of the International Congress on Environmental Geotechnics, 4th, Rio de Janeiro, Brazil.

57. Albaiges J, Casado F, Ventura F (1986) Organic indicators of groundwater pollution by a sanitary landfill. Water Research 20: 1153-1159.

58. Schwarzbauer J1, Heim S, Brinker S, Littke R (2002) Occurrence and alteration of organic contaminants in seepage and leakage water from a waste deposit landfill. Water Res 36: 2275-2287.

59. Heim, Sabine, Schwarzbauer, Jan, Littke, Ralf (2004) Monitoring of waste deposit derived groundwater contamination with organic tracers. Environ Chem Lett 2: 21-25.

60. Vahcic, Mitja, Milacic, Radmila, Scancar, Janez (2011) Development of analytical procedure for the determination of methyltin, butyltin, phenyltin and octyltin compounds in landfill leachates by gas chromatography-inductively coupled plasma mass spectrometry. Analytica Chimica Acta. 694: 21-30.

61. Bjoern, Annika (2010) Leaching of organotin stabilizers from PVC under prevailing landfill conditions. Advances in Chemistry Research 3: $669-673$.

62. Bergstroem, Staffan, Svensson, Britt-Marie, Maartensson, Lennart, Mathiasson, Lennart (2007) Development and application of an 
Citation: Harwood JJ (2014) Where Did That Pollution Come From? A Review of Chemical and Microbial Markers of Organic Pollution. Int J Waste Resources 4: 159. doi:10.4172/2252-5211.1000159

Page 7 of 7

analytical protocol for evaluation of treatment processes for landfil leachates I Development of an analytical protocol for handling organic compounds in complex leachate samples. International Journal of Environmental Analytical Chemistry 87: 1-15.

63. Mohammadzadeh, Hossein, Clarka, Ian, Marschnera, Mark, St-Jean, Gilles (2005) Compound Specific Isotopic Analysis (CSIA) of landfill leachate DOC components. Chemical Geology 218: 3-13.

64. North, Jessica C, Frew, Russell D, Peake, Barrie M (2004) The use of carbon and nitrogen isotope ratios to identify landfill leachate contamination: Green Island Landfill, Dunedin, New Zealand/ Environment International 30: 631-637.

65. Mangani, Giovanna, Berloni, Arnaldo, Bellucci, Francesca, Tatano, Fabio, Maione, Michela, (2005) Evaluation of the pollutant content in road runoff first flush water. Water, Air, Soil Pollutution 160: 213-228.

66. Kumata, Hidetoshi, Sanada, Yukihisa, Takada, Hideshige, Ueno, Takashi (2000) Historical Trends of N-Cyclohexyl-2-benzothiazolamine, 2-(4Morpholinyl) benzothiazol and Other Anthropogenic Contaminants in the Urban Reservoir Sediment Core. Environmental Science \& Technology 34: 246-253.
67. Kumata H1, Takada H, Ogura N (1996) Determination of 2-(4Morpholinyl)benzothiazole in Environmental Samples by a Gas Chromatograph Equipped with a Flame Photometric Detector. Anal Chem 68: 1976-1981.

68. Kumata, Hidetoshi, Yamada, Junya, Masuda, Kouji, Takada, Hideshige, Sato, Yukio (2002) Benzothiazolamines as Tire-Derived Molecular Markers: Sorptive Behavior in Street Runoff and Application to Source Apportioning. Environmental Science \& Technology 36: 702-708.

69. Zeng EY1, Tran K, Young D (2004) Evaluation of potential molecular markers for urban stormwater runoff. Environ Monit Assess 90: 23-43.

70. Murakami, Michio, Yamada, Junya, Kumata, Hidetoshi, Takada, Hideshige (2008) Sorptive Behavior of Nitro-PAHs in Street Runoff and Their Potential as Indicators of Diesel Vehicle Exhaust Particles. Environmental Science \& Technology 42: 1144-1150.

71. Kose, T, Yamamoto, T, Anegawa, A, Mohri, S, Ono, Y (2008) Source analysis for polycyclic aromatic hydrocarbon in road dust and urban runoff using marker compounds. Desalination 226: 151-159. 